\title{
Hormonal Control of Adrenocortical Cell Proliferation
}

\author{
DESENSITIZATION TO ACTH AND́ INTERACTION \\ BETWEEN ACTH AND FIBROBLAST GROWTH FACTOR \\ IN BOVINE ADRENOCORTICAL CELL CULTURES
}

\author{
Peter J. Hornsby and Gordon N. Gill \\ From the Department of Medicine, Division of Endocrinology, University of California, \\ San Diego, School of Medicine, La Jolla, California 92093
}

\begin{abstract}
A B S T RACT A primary bovine adrenocortical cell culture system responsive to physiological concentrations of ACTH has been established. When added to cultures, ACTH inhibited DNA synthesis and cell division over the same concentration range required for stimulation of fluorogenic steroid production (0.01$10 \mathrm{nM}$ ). With chronic exposure to ACTH, cells became desensitized to the growth inhibitory effects of ACTH. Though cell growth was initially completely inhibited by ACTH, cells ultimately began to grow in its continued presence. The lag time to initiation of cell growth, the rate of growth, and the final density achieved depended on the ACTH concentration. Desensitization to $\mathrm{ACTH}_{1-39}$ was not induced by monobutyryl cyclic AMP nor by $\mathrm{ACTH}_{11-24}$. Specificity of desensitization was apparent because cells which had become desensitized to $\mathrm{ACTH}_{1-39}$ remained fully responsive to monobutyryl cyclic AMP, prostaglandin $E_{1}$, and cholera toxin. Though the effects of ACTH on cell growth were readily reversible upon hormone removal, the desensitized response to readdition of ACTH persisted for at least $8 \mathrm{~h}$.

Fibroblast growth factor (FGF) stimulated both the growth rate and saturation density achieved. FGF did not alter the growth inhibitory effects of ACTH nor the reduced growth rate observed in desensitized cells maintained in ACTH. However, FGF greatly increased the saturation density achieved by cultures maintained with ACTH.
\end{abstract}

Dr. Hornsby was a Postdoctoral Research Fellow of the Science Research Council, London. Dr. Gill is the recipient of U.S. Public Health Service Research Career Development Award AM70215 from the National Institute of Arthritis, Metabolism, and Digestive Diseases.

Received for publication 20 September 1976 and in revised form 28 January 1977.
Through the process of desensitization, adrenocortical cells are able to grow in the presence of high concentrations of ACTH and to respond to the effects of a growth factor by increasing the cell density achieved. This pattern of response may be a general one for growth control under the combined effects of antimitotic and mitotic factors.

\section{INTRODUCTION}

Experiments with cultured adrenocortical cells derived from either normal tissue $(1,2)$ or an adrenal tumor (Y-1 cells) (3) have established that the direct action of $\mathrm{ACTH}^{1}$ on the adrenocortical cell is antimitotic. It has therefore been suggested that the stimulatory action of ACTH on adrenal cell division in vivo may be indirect $(4,5)$, possibly being mediated by a growth factor. One of the known growth factors, fibroblast growth factor (FGF) has been demonstrated to be mitogenic for both normal (4) and tumor (6) adrenocortical cells in culture. If such a growth factor acts in vivo, its effect would be opposed by the direct anti-growth action of ACTH. This activity of ACTH has been shown, in studies in cultured Y-1 cells, to be most pronounced in the inhibition of DNA synthesis, with RNA and protein synthesis being little affected (5). Because RNA and protein synthesis are stimulated by serum growth factors and the steroidogenic pathway by ACTH, the result is a hypertrophied hyperfunctional adrenocortical cell $(5,7)$. This correlates well with the action of ACTH

\footnotetext{
${ }^{1}$ Abbreviations used in this paper: $\mathrm{ACTH}$ or $\mathrm{ACTH}_{1-39}$, full porcine pituitary ACTH molecule; $\mathrm{ACTH}_{11-24}$, synthetic corticotropin-(11-24)-tetradeca-peptide; cAMP, cyclic AMP; FGF, fibroblast growth factor; LH, luteinizing hormone.
} 
in vivo $(8,9)$. Nevertheless, adrenal cell division does occur in vivo in the presence of elevated levels of ACTH (9-12), particularly under such conditions as adrenal regeneration (13). We have therefore investigated in detail the effects of ACTH on the proliferation of normal adult bovine adrenocortical cells in monolayer culture, studying in particular the results of prolonged ACTH treatment and the interaction of ACTH with the one known mitogenic hormone for the adrenal cell, FGF.

\section{METHODS}

Preparation of cultures. The method of preparing a suspension of adrenocortical cells from bovine adrenal glands has been previously described (4). $20 \mathrm{ml}$ of cell suspension was obtained per gland. Additional fetal calf serum was added to make the total serum concentration $20 \%$, and dimethyl sulfoxide (Mallinckrodt Inc., St. Louis, Mo.) added to give a $5 \%$ solution. The cell suspension was then divided into 2-ml aliquots which were placed in vials and frozen in liquid nitrogen. Cells remained viable for at least 6 mo and multiple experiments could be performed with the same cell preparation. Vials were subsequently recovered from liquid nitrogen as required, unfrozen and diluted in an appropriate volume of Coon and Weiss' modification (14) of Ham's F-12 medium (Grand Island Biological Co., Grand Island, N. Y.) with $10 \%$ fetal calf serum (Irvine Scientific Sales Co., Fountain Valley, Calif.). The same batch of fetal calf serum was used throughout the present experiments. Medium contained $100 \mu \mathrm{g} / \mathrm{ml}$ penicillin G (Sigma Chemical Co., St. Louis, Mo.) and $50 \mu \mathrm{g} / \mathrm{ml}$ gentamicin (Sigma Chemical Co.). The diluted cell suspension was placed in tissue culture plates (Falcon Plastics, Div. of BioQuest, Oxnard, Calif.) and the cells allowed to attach to the plastic for $6 \mathrm{~h}$. The medium was then renewed.

Measurement of cell number. Medium was removed from cultures and replaced with $1 \mathrm{ml}$ Tris-buffered saline containing $0.05 \%$ trypsin and $5 \mathrm{mM}$ EDTA. After $10 \mathrm{~min}$ at room temperature the cells were removed from the plate by flushing with a Pasteur pipette, diluted with an appropriate volume of phosphate-buffered saline, and counted immediately with a Coulter Counter, model $\mathrm{Z}_{\mathrm{F}}$ (Coulter Electronics Inc., Hialeah, Fla.).

Measurement of $\left[{ }^{3} \mathrm{H}\right]$ thymidine incorporation and autoradiography. $\left[{ }^{3} \mathrm{H}\right]$ Thymidine $(60 \mathrm{Ci} / \mathrm{mmol}, 10 \mu \mathrm{Ci} / \mathrm{plate})$ (Schwarz/Mann Div., Becton, Dickinson \& Co., Orangeburg, N. Y.) was added to the cultures without medium change. $4 \mathrm{~h}$ later the radioactive medium was removed, the cultures washed with phosphate-buffered saline, and $1 \mathrm{ml}$ of a $1 \%$ aqueous solution of Triton X-100 (Sigma Chemical Co.) added. The solution was left to solubilize the cells for $5 \mathrm{~min}$ and then transferred to $10 \mathrm{ml}$ of absolute ethanol. This material was filtered under vacuum through a $2.4-\mathrm{cm}$ diameter glass fiber filter (Whatman GF/A, W. \& R. Balston Ltd., England), and the filter washed twice with $10 \mathrm{ml}$ absolute ethanol. The filter was then counted in tolueneLiquifluor (New England Nuclear, Boston, Mass.) (3.8 liters: $160 \mathrm{ml}$ ).

The procedure for autoradiography was that described by Holley and Kiernan (15).

Cell cycle analysis by flow microfluorometry. Cells were prepared for flow microfluorometer analysis by mithramycin staining (16) and analyzed in a Los Alamos design microfluorometer with an argon laser at $488 \mathrm{~nm}$. Analysis of the distribution of cells with varying DNA contents was performed by the graphic method of Holley and Kiernan (17).

Measurement of fluorogenic steroids. Fluorogenic steroids (principally cortisol and corticosterone) were measured by a modification of the sulfuric acid-induced fluorescence method (18). The culture medium was extracted with $3 \mathrm{vol}$ of dichloromethane and the extract mixed with $2 \mathrm{ml}$ of a $65 \%$ solution of sulfuric acid in $95 \%$ ethanol. After $1 \mathrm{~h}$ the fluorescent emission at $520 \mathrm{~nm}$ of the sulfuric acid-ethanol mixture resulting from $470 \mathrm{~nm}$ excitation was measured and compared to that of a cortisol standard. Because the primary steroid product of bovine adrenocortical cells is cortisol (19), results are expressed as micrograms of cortisol standard.

\section{Materials}

Purified porcine $\mathrm{ACTH}_{1-39}$ was obtained from Armour Pharmaceutical Co., Phoenix, Ariz. An appropriate volume of $0.1 \mathrm{M}$ acetic acid was added to a 25-U vial on the day of use. ACTH solutions were not stored. Before addition to the cultures, the ACTH solution was mixed with culture medium to the extent of $1 \%$ by volume, and then added to the culture immediately. The same volume of $0.1 \mathrm{M}$ acetic acid was added to control cultures.

ACTH $_{11-24}$ (the gift of Dr. Rittel of Ciba-Geigy, Basal, Switzerland) was dissolved in $0.1 \mathrm{M}$ acetic acid before use.

Purified FGF was the gift of Dr. Denis Gospodarowicz, The Salk Institute, La Jolla, Calif. FGF was dissolved in phosphate-buffered saline, $\mathrm{pH} 7.4$, with $0.5 \%$ bovine serum albumin (Sigma Chemical Co.) and the solution was mixed with culture medium to the extent of $5 \%$ by volume immediately before adding to cultures.

Monobutyryl cyclic AMP (Sigma Chemical Co.) was dissolved in phosphate-buffered saline before use. Prostaglandin $E_{1}$ (the gift of Dr. J. Pike of Upjohn Co., Kalamazoo, Mich.) was dissolved in $95 \%$ ethanol. The solution was mixed to the extent of $1 \%$ by volume with culture medium prior to addition to cultures. Control cultures also received $1 \%$ ethanol. Cholera toxin was from Schwarz/Mann Div., Becton, Dickinson \& Co. A $1 \mathrm{mg}$ vial was reconstituted with $1 \mathrm{ml}$ distilled water and further diluted with phosphate-buffered saline.

Mithramycin was obtained from Pfizer Inc., New York. Aminoglutethimide (Elipten phosphate) was a gift from CibaGeigy Corp., Summit, N. J., and was dissolved in dimethyl sulfoxide for addition to culture medium at $1 \%$ by volume.

\section{RESULTS}

Acute responsiveness to ACTH. In the bovine adrenocortical cell system, responsiveness to physiological concentrations of ACTH was demonstrated by dose-response curves for ACTH which indicated halfmaximal fluorogenic steroid production at approximately $0.5 \mathrm{nM} \mathrm{ACTH} \mathrm{(Fig.} \mathrm{1).} \mathrm{Similar} \mathrm{dose-response}$ curves were obtained at the initiation of cell growth (day 1), during log growth (day 4), and as cells entered the stage of density-dependent inhibition of cell growth (day 6) (see Fig. 4). Previous studies indicated that these cells contained abundant lipid as demonstrated by oil-red $O$ staining and gave a strongly positive histochemical stain for $\Delta^{5} 3-\beta$-hydroxysteroid dehydrogenase (4). 


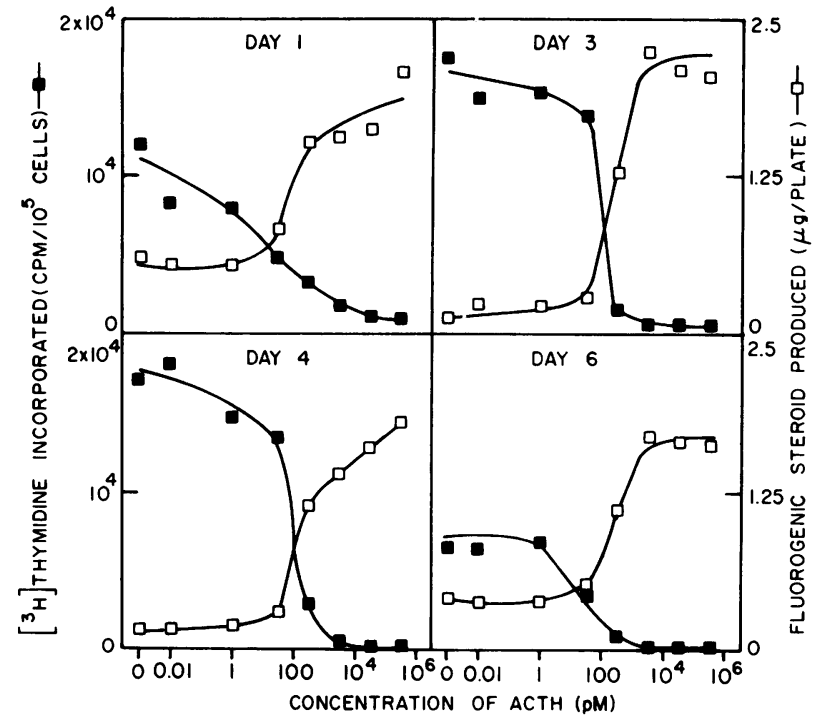

FIGURE 1 Effect of ACTH on fluorogenic steroid production and on $\left[{ }^{3} \mathrm{H}\right]$ thymidine incorporation into DNA. Bovine adrenocortical cells were plated and grown as described under Methods. After 1, 3, 4, or 6 days, fresh medium containing the indicated concentrations of ACTH was added. $16 \mathrm{~h}$ after ACTH addition, $\left[{ }^{3} \mathrm{H}\right]$ thymidine was added for $4 \mathrm{~h}$. The medium was removed for analysis of steroid production over this 20 -h period and cells were assayed for $\left[{ }^{3} \mathrm{H}\right]-$ thymidine incorporation into DNA. Fluorogenic steroid production, ( $\square$ ); $\left[{ }^{3} \mathrm{H}\right]$ thymidine incorporation into DNA, (ם).

When the adrenal cells which had grown to confluence were subcultured, the steroidogenic capacity per cell was found to be equal to that of freshly prepared cultures whether the subcultured cells had previously been maintained with ACTH or in its absence (Fig. 2). In this experiment cells which had grown to confluence in the absence or presence of $10 \mathrm{nM}$ ACTH were subcultured and grown without ACTH to a density of $10^{5}$ cells/plate. Cholera toxin, which is a potent stimulator of steroidogenesis in cultured adrenocortical cells (20), was added to assess maximal steroidogenic capacity independently of any alterations in ACTH sensitivity due to pretreatment. A progressive increase in steroidogenic capacity was seen in both freshly plated and subcultured cells; the same maximum rate of steroid production per cell was reached by day 4 . The increasing steroidogenic capacity with prolonged cholera toxin treatment resembles that seen with prolonged ACTH treatment in other adrenal cell culture systems (7, 21-23); this increased steroidogenic capacity is due to progressive stimulation of steroidogenic pathway enzymatic activity. Cloned cell lines derived from these primary normal bovine adrenocortical cell cultures retain the same steroidogenic capacity over many generations; continuously passaged cultures also

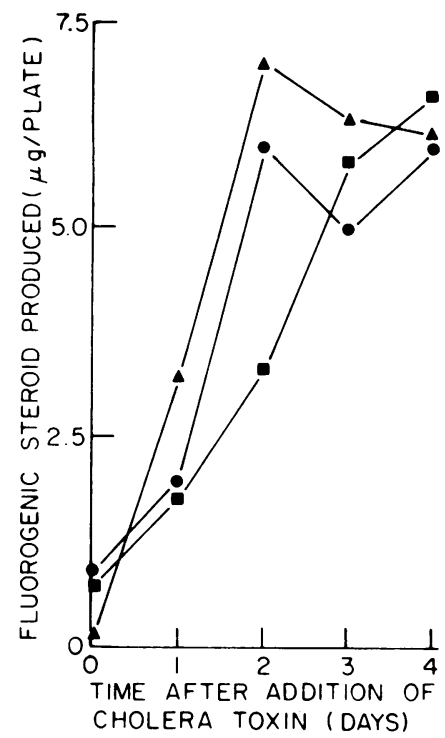

FIGURE 2 Steroidogenic capacity of bovine adrenocortical cells after subculture. The steroidogenic capacity of cells grown for prolonged periods in the presence or absence of ACTH was compared to that of freshly plated cells. Three groups of cells were compared: Freshly plated cultures of $10^{5}$ cells/plate, $(\Delta)$; cells grown to confluence in the absence of ACTH which were subcultured and grown to $10^{5}$ cells/plate, $(\square)$; and cells grown to confluence in the presence of $10 \mathrm{nM}$ ACTH which were subcultured and grown to $10^{5}$ cells/plate in the absence of ACTH, (O). The experiment was initiated by addition of fresh medium with $1 \mathrm{nM}$ cholera toxin. Every $24 \mathrm{~h}$, medium was removed for determination of fluorogenic steroid production and fresh medium containing $1 \mathrm{nM}$ cholera toxin added. In the presence of cholera toxin, maximal steroidogenesis is observed (20) and cell growth does not occur (see Fig. 6).

retain the same steroidogenic capacity for over 50 generations. ${ }^{2}$ In both instances the cell population gives a uniformly positive stain for $\Delta^{5} 3-\beta$-hydroxysteroid dehydrogenase.

ACTH inhibits DNA synthesis as previously reported for Y-1 and normal rat adrenocortical cells (1-3). When ACTH was added for $16-\mathrm{h}$ periods to cultures at any stage of their growth, $>98 \%$ of $\left[{ }^{3} \mathrm{H}\right]-$ thymidine incorporation into DNA was inhibited (Fig. 1). The ACTH dose response for inhibition of $\left[{ }^{3} \mathrm{H}\right]$ thymidine incorporation was similar to that observed for stimulation of steroidogenesis and similar ACTH sensitivity was observed at all stages of cell growth. The complete inhibition of $\left[{ }^{3} \mathrm{H}\right]$ thymidine incorporation into DNA by ACTH indicates that the population is almost purely adrenocortical in origin. In contrast, $\mathrm{ACTH}$ up to $1 \mu \mathrm{M}$ had no effect on $\left[{ }^{3} \mathrm{H}\right]$ thymidine incorporation into primary cultures of bovine lung cells from similar animals. Autoradiog-

${ }^{2}$ Hornsby, P. J., and G. N. Gill. Manuscript in preparation. 
raphy showed that $>98 \%$ of freshly plated bovine adrenal cells became labeled with $\left[{ }^{3} \mathrm{H}\right]$ thymidine and that $>98 \%$ of cells are labeled during log growth during one generation time indicating no substantial subpopulation of nondividing cells (see Fig. 5). By autoradiography, ACTH was shown previously to inhibit DNA synthesis in $>98 \%$ of the cells (4).

When ACTH-treated cells were examined by flow microfluorometry, a predominant $\mathrm{G}_{1}$ arrest was observed. As shown in Fig. 3, randomly growing cells are distributed throughout the cell cycle. When ACTH was added to parallel cultures for $24 \mathrm{~h}$, cells with a $\mathrm{G}_{1}$ complement of DNA predominated. Analysis of the results showed that in control cultures $34 \%$ of cells are in $\mathrm{G}_{1}, 31 \%$ in $\mathrm{S}$ and $35 \%$ in $\mathrm{G}_{2}+\mathrm{M}$. In ACTHtreated cultures, $79 \%$ of cells were in $G_{1}, 5 \%$ in $S$, and $16 \%$ in $\mathrm{G}_{2}+\mathrm{M}$. This $\mathrm{G}_{1}$ growth arrest with ACTH addition is identical to that observed in Y-1 functional mouse adrenal cortical tumor cells $(5,7)$.

Treatment of cultures with aminoglutethimide, an inhibitor of the conversion of cholesterol to pregnenolone (24), reduced the ACTH and monobutyryl cyclic AMP (cAMP)-stimulated level of steroid production to the nonstimulated level seen in the absence of aminoglutethimide (Table I). Under these conditions, ACTH and monobutyryl cAMP continued to reduce $\left[{ }^{3} \mathrm{H}\right]$ thymidine incorporation into DNA to the same extent as in the non-aminoglutethimide-treated cultures. ACTH does not appear to inhibit adrenal cell proliferation through its stimulation of steroidogenesis but by raising the intracellular concentration of cAMP (3). The cultured cells behaved therefore as a single population of adrenocortical cells with respect to cell division, responsiveness to ACTH, and retention of steroidogenic capacity.

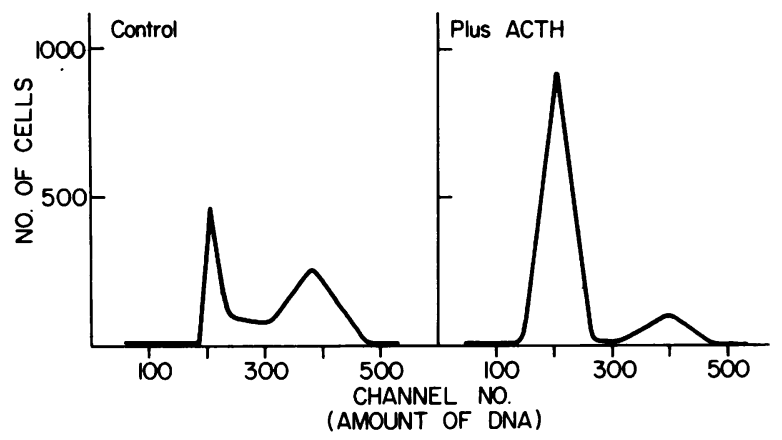

FIGURE 3 Flow microfluorometric analysis of the effect of ACTH on randomly growing primary bovine adrenal cortical cells. Cells were plated at $2 \times 10^{4}$ cells per plate and grown in $10 \%$ fetal calf serum for 3 days before the addition of $10 \mathrm{nM}$ ACTH. $24 \mathrm{~h}$ later, ACTH-treated and control cells were harvested and treated as described under Methods. The number of cells assayed by flow microfluorometry was 50,000 for the control cultues and 56,000 for the ACTHtreated cultures.
TABLE I

Effect of Aminoglutethimide on ACTH and Monobutyryl cAMP Stimulation of Steroidogenesis and Inhibition of DNA Synthesis

\begin{tabular}{|c|c|c|c|c|}
\hline \multirow[b]{2}{*}{ Treatment } & \multicolumn{2}{|c|}{ Steroid production } & \multicolumn{2}{|c|}{$\begin{array}{c}{\left[{ }^{3} \mathrm{H}\right] \text { Thymidine }} \\
\text { incorporation }\end{array}$} \\
\hline & None & $\begin{array}{c}\text { Amino- } \\
\text { glutethimide }\end{array}$ & None & $\begin{array}{c}\text { Amino- } \\
\text { glutethimide }\end{array}$ \\
\hline & \multicolumn{2}{|c|}{$\mu g / 24 h$} & \multicolumn{2}{|c|}{$\%$ control } \\
\hline Control & 1.4 & 0.2 & 100 & 105 \\
\hline ACTH (10 nM) & 5.2 & 1.3 & 3.8 & 3.5 \\
\hline Monobutyryl & & & & \\
\hline $\operatorname{cAMP}(1 \mathrm{mM})$ & 8.6 & 1.5 & 1.7 & 2.6 \\
\hline
\end{tabular}

Cultures were treated for 2 days with $300 \mu \mathrm{g} / \mathrm{ml}$ aminoglutethimide. The medium was then replaced without additions or with the addition of $10 \mathrm{nM} \mathrm{ACTH}$ or $1 \mathrm{mM}$ monobutyryl cAMP. $18 \mathrm{~h}$ later, $\left[{ }^{3} \mathrm{H}\right]$ thymidine was added, and after an additional $4 \mathrm{~h}$ the medium was removed for assay of steroids and the cells were harvested for measurement of incorporation of radioactivity. Control cultures showed an incorporation of $2.7 \times 10^{4} \mathrm{cpm} / 10^{5}$ cells.

Cell growth in the presence of chronically elevated ACTH levels. When primary bovine adrenocortical cells were maintained in the presence of elevated ACTH concentrations, a characteristic pattern of growth resulted (Fig. 4). In the absence of ACTH there was a lag of 2 days during which no increase in

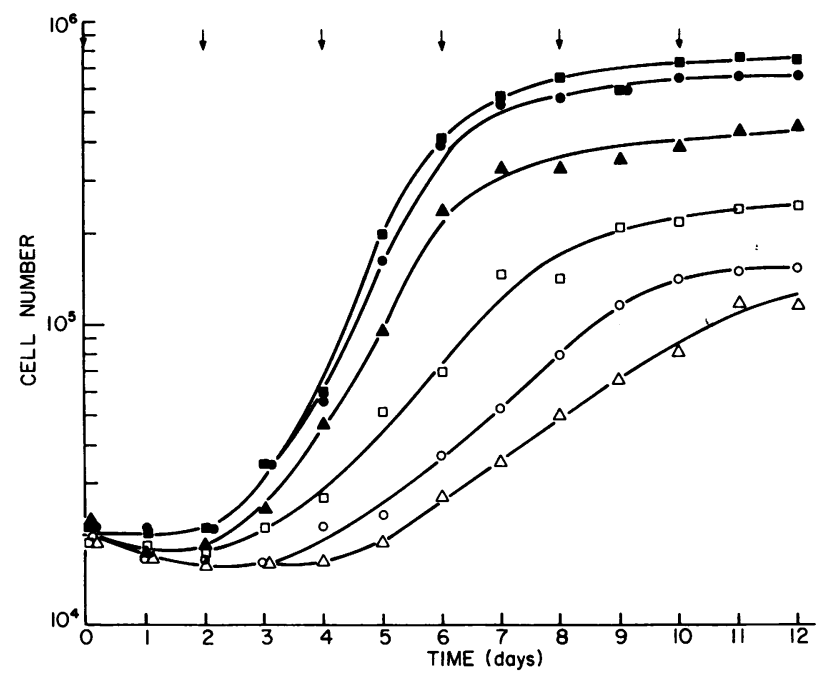

FigURE 4 Growth of adrenocortical cells in the continuous presence of varying concentrations of ACTH. $6 \mathrm{~h}$ after cells were plated, fresh F-12 medium containing $10 \%$ fetal calf serum was added, without ACTH ( $\square$ ) or with the addition of the following concentrations of ACTH: 1 pM, (O); 10 $\mathrm{pM},(\Delta) ; 100 \mathrm{pM},(\square) ; 1 \mathrm{nM}(O) ; 10 \mathrm{nM},(\Delta)$. The medium, with the same concentrations of $\mathrm{ACTH}$, was renewed at 2-day intervals as indicated by the arrows. 
cell number was detected. Cells then entered a period of exponential growth followed by a leveling of the growth curve to a plateau.

When ACTH was continuously present, all three of these growth stages were affected. The lag period was prolonged, the prolongation being dependent upon the ACTH concentration. The early slight decrease in cell number at the higher ACTH levels resulted from retraction (25), detachment, and loss of a small number of cells. After this lag period, cells at all doses of ACTH tested entered a period of exponential growth despite the continuous addition of ACTH at each change of the culture medium. The rate of growth depended upon the ACTH concentration. In the absence of ACTH, the average doubling time of the cell population equaled $24 \mathrm{~h}$; in the presence of 10 $\mathrm{nM}$ ACTH the doubling time equaled $48 \mathrm{~h}$. The exponential growth phase was followed by cessation of growth which occurred at a reduced cell density which was dependent upon the ACTH concentration present. At $10 \mathrm{nM} \mathrm{ACTH}$ plateauing of the increase in cell number occurred at $20 \%$ of the density achieved in its absence. The plateauing of increase in cell number was not due to accelerated cell death but to markedly reduced DNA synthesis and cell division. When DNA synthesis in ACTH-treated cells whose cell number had plateaued was compared to that of cells during log growth, $\left[{ }^{3} \mathrm{H}\right]$ thymidine incorporation into DNA was reduced to $<5 \%$ of that of cultures growing in the presence of ACTH. Density-dependent inhibition of cell growth therefore occurs both with and without ACTH.

The pattern of a lag followed by exponential growth indicated that the cells must undergo considerable desensitization to the original inhibitory effect of ACTH (Fig. 1). The cells maintain a constant lower level of responsiveness to ACTH as shown by the reduced but constant growth rate which was dependent upon the ACTH concentration.

The cell population appeared uniformly affected. Autoradiography of cells labeled with $\left[{ }^{3} \mathrm{H}\right]$ thymidine for one generation while growing in the presence of ACTH revealed no substantial subpopulation of nondividing cells indicating that ACTH is not preferentially inhibiting some cells (Fig. 5). It appears that the whole population divides at the reduced rate in the presence of ACTH. The fact that these are adrenal cells was confirmed by the demonstration that cells taken from a culture grown to confluence in the presence of ACTH have the same steroidogenic capacity as cells from a non-ACTH-treated culture or freshly plated cells (Fig. 2).

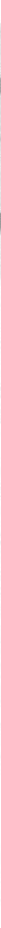

FIGURE 5 Autoradiography of bovine adrenocortical cells under differing growth conditions. Cells were pulsed with $\left[{ }^{3} \mathrm{H}\right]$ thymidine for one cell doubling and prepared for autoradiography as described under Methods. (A) Freshly plated cells incubated with $\left[{ }^{3} \mathrm{H}\right]$ thymidine for a 48-h period 2 days after plating out. (B) Cells in the log growth phase (day 4). (C) Cells in the $\log$ growth phase in the continuous presence of $10 \mathrm{nM}$ ACTH (day 6). 
Effect of $\mathrm{ACTH}_{11-24}$ and monobutyryl cAMP on cell growth. When a high concentration of $\mathrm{ACTH}_{1-39}$ (10 $\mathrm{nM}$ ) was added to cultures during exponential growth, an approximate doubling of cell number occurred, followed by cessation of growth within $24 \mathrm{~h}$ (Fig. 6). This response correlates with inhibition of $\left[{ }^{3} \mathrm{H}\right]$ thymidine incorporation into DNA (Fig. 1), and with the $G_{1}$ point of growth arrest (Fig. 3).

In contrast, when the adrenocortical cells were maintained in the presence of a high concentration $(10 \mu \mathrm{M})$ of an ACTH fragment $\left(\mathrm{ACTH}_{11-24}\right)$, no significant effect on cell growth occurred (Fig. 6). This $\mathrm{ACTH}_{11-24}$ fragment acts as a competitive inhibitor of $\mathrm{ACTH}_{1-39}$ by binding to ACTH receptor sites but lacks the amino terminal portion required for biological activity $(26,27)$.

Monobutyryl cAMP stimulates steroidogenesis and inhibits $\left[{ }^{3} \mathrm{H}\right]$ thymidine incorporation into DNA in the bovine adrenocortical cell system. When cells were maintained with a concentration of monobutyryl cAMP ( $1 \mathrm{mM})$, equivalent to $10 \mathrm{nM}$ ACTH in inhibiting $\left[{ }^{3} \mathrm{H}\right]$ thymidine incorporation, cell growth did not occur (Fig. 6). This persistent growth inhibition contrasts with the resistance to the growth inhibitory effects of $\mathrm{ACTH}_{1-39}$ which developed over this time period.

Effect of desensitization to ACTH on responsiveness to monobutyryl cAMP, prostaglandin $E_{1}$, and cholera toxin. The incorporation of $\left[{ }^{3} \mathrm{H}\right]$ thymidine into DNA

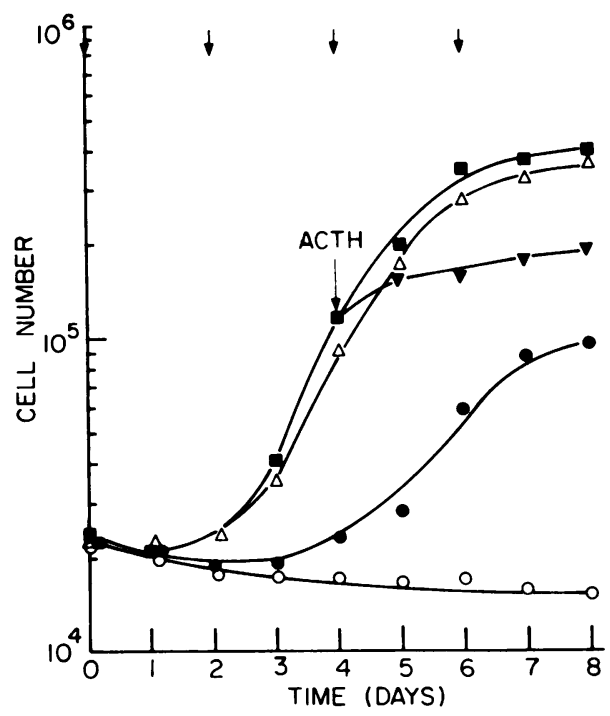

FIGURE 6 Effect of ACTH 11-24 $_{1}$ and monobutyryl cAMP on cell growth. Medium with serum and the indicated additions was replenished every 2 days as indicated by the arrows at the top of the diagram. Normal medium without additions, $(\square)$; plus monobutyryl cAMP (1 $\mathrm{mM}),(\mathrm{O})$; plus $\mathrm{ACTH}_{11-24}(10 \mu \mathrm{M}),(\Delta)$; plus $\mathrm{ACTH}_{1-39}(10 \mathrm{nM}),(\Theta)$; normal medium without additions until day 4 when ACTH (10 $\mathrm{nM}$ ) was added as indicated by arrow, ( $)$. in growing bovine adrenocortical cells is inhibited by monobutyryl cAMP, prostaglandin $\mathrm{E}_{1}$, and cholera toxin (Fig. 7). ACTH, prostaglandin $\mathrm{E}_{1}$, and cholera toxin have all been reported to elevate cAMP levels in adrenocortical cells (28-30). When cells which have become desensitized to the growth inhibitory effects of $10 \mathrm{nM} \mathrm{ACTH}$ were tested for sensitivity to monobutyryl cAMP, prostaglandin $\mathrm{E}_{1}$, and cholera toxin, sensitivity equivalent to control cultures was noted (Fig. 7). Though initial $\left[{ }^{3} \mathrm{H}\right]$ thymidine incorporation over a 4-h period was lower, consistent with the prolonged average cell cycle time of ACTH-treated cultures, no change in the dose-response curves occurred indicating that desensitization to ACTH did not cause desensitization to these other substances.

Pretreatment with monobutyryl cAMP or with $\mathrm{ACTH}_{11-24}$ did not cause the development of insensitivity to $\mathrm{ACTH}_{1-39}$. When inhibitory concentrations of monobutyryl cAMP ( $1 \mathrm{mM})$ were removed, cell growth resumed. Addition of $\mathrm{ACTH}_{1-39}$ inhibited $\left[{ }^{3} \mathrm{H}\right]-$ thymidine incorporation over the same concentration range as in control cultures (Fig. 8). Exposure to 10 $\mu \mathrm{M} \mathrm{ACTH} \mathrm{Al}_{11-24}$ did not affect the subsequent responsiveness to $\mathrm{ACTH}_{1-39}$. This concentration of $\mathrm{ACTH}_{11-24}$ was shown to be effective in inhibiting by $50 \%$ steroidogenesis stimulated by $10 \mathrm{nM} \mathrm{ACTH}{ }_{1-39}$ when added simultaneously to cultures (data not shown). The apparent receptor affinity for $\mathrm{ACTH}_{1-39}$ relative to $\mathrm{ACTH}_{11-24}$ of 1,000:1 is greater than that reported for binding to receptors in a membrane preparation (27) and may reflect different half-lives of $\mathrm{ACTH}_{1-39}$ and $\mathrm{ACTH}_{11-24}$ which have been shown to be degraded by different mechanism (31). This competitive antagonist of ACTH action did not induce the desensitization caused by $\mathrm{ACTH}_{1-39}$.

Pretreatment with $100 \mathrm{ng} / \mathrm{ml}$ FGF which stimulated

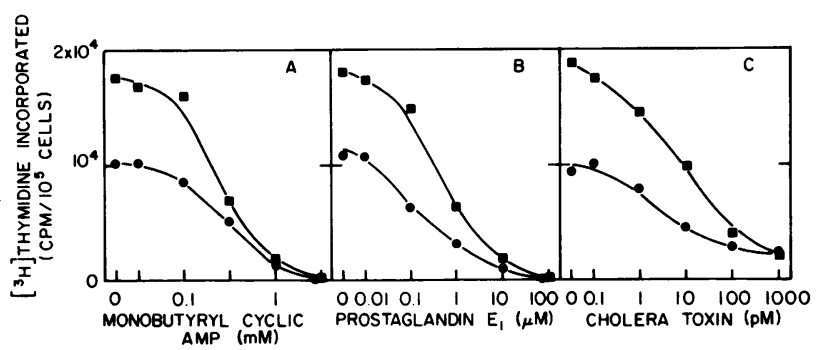

FIGURE 7 Effect of monobutyryl cAMP, prostaglandin $E_{1}$, and cholera toxin on $\left[{ }^{3} \mathrm{H}\right]$ thymidine incorporation into DNA in control cells and in cells desensitized to ACTH. Control cells were grown for 4 days in the absence of ACTH and desensitized cells were grown for 6 days in the presence of $10 \mathrm{nM}$ ACTH. Medium was removed and fresh medium containing the indicated concentrations of monobutyryl cAMP, prostaglandin $E_{1}$, or cholera toxin added. $16 \mathrm{~h}$ later the cells were pulsed for $4 \mathrm{~h}$ with $\left[{ }^{3} \mathrm{H}\right]$ thymidine and incorporation into DNA determined as described under

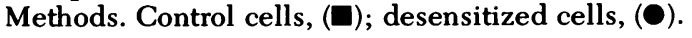




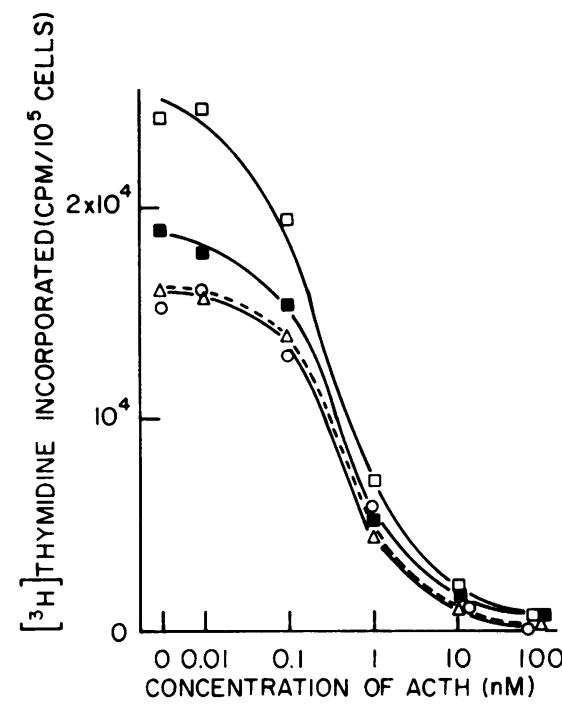

FIGURE 8 Effect of treatment with $\mathrm{ACTH}_{11-24}$, monobutyryl cAMP, and FGF on subsequent responsiveness to ACTH $_{1-39}$. Cells were grown for 4 days with or without the indicated additions. Medium was removed and cells washed twice by incubation with fresh medium for 30 $\mathrm{min}$ to remove hormones. Fresh medium containing the indicated concentrations of $\mathrm{ACTH}_{1-39}$ was then added. $16 \mathrm{~h}$ later cells were pulsed for $4 \mathrm{~h}$ with $\left[{ }^{3} \mathrm{H}\right]$ thymidine and incorporation into DNA determined as described under Methods. Control, $(\square)$; pretreatment with $\mathrm{ACTH}_{11-24}$ (10 $\boldsymbol{\mu} \mathrm{M}),(\triangle)$; pretreatment with $\mathrm{FGF}(100 \mathrm{ng} / \mathrm{ml}),(\square)$; pretreatment with monobutyryl cAMP (1 mM), (O).

$\left[{ }^{3} \mathrm{H}\right]$ thymidine incorporation and cell growth (4) did not affect the $50 \%$ effective dose of ACTH required for inhibition of DNA synthesis (Fig. 8).

Reversibility of growth inhibition due to ACTH. When ACTH is removed from cultures which have become desensitized, i.e., have entered the exponential phase of cell growth in the presence of ACTH, the rate of growth increases and a higher saturation plateau is achieved (Fig. 9).

Though the rate of cell growth and saturation density increase when ACTH is removed, cells remain resistant to subsequently added ACTH. When cultures which had become desensitized to $10 \mathrm{nM}$ ACTH and were growing at a reduced rate in its presence were washed and incubated for an additional period with 0.01$100 \mathrm{nM}$ ACTH, there was much less inhibition of $\left[{ }^{3} \mathrm{H}\right]$ thymidine incorporation at any dose tested compared to nontreated cultures (Fig. 10). The flattened dose-response curve persisted when cells were incubated for $8 \mathrm{~h}$ in ACTH-free medium before subsequent addition of ACTH. The increased rate of cell growth upon ACTH removal suggests that the insensitivity to ACTH is not due to ACTH from the original exposure remaining bound to receptors. Bound ACTH is released from receptors with a half-life of $3 \mathrm{~min}$ at $37^{\circ} \mathrm{C}$ (27). Initial exposure to $10 \mathrm{nM}$ ACTH for 20 min, a time sufficient to saturate ACTH receptors, followed by normal washing had no effect on the subsequent response to ACTH; i.e., cells remained sensitive to ACTH giving an identical response to the control curve shown in Fig. 10. Pretreatment for 6 days with a lower concentration of ACTH $(0.1 \mathrm{nM})$ resulted in a dose-response curve which on subsequent incubation with 0.01-100 nM ACTH showed partial desensitization. This dose-response curve was intermediate between that seen with $10 \mathrm{nM}$ ACTH and no pretreatment. As seen in Fig. 10, desensitization results in a decrease in maximum responsiveness to subsequent ACTH.

Interaction of ACTH and FGF on proliferation. As previously demonstrated (4), FGF was effective in promoting the growth of cultured adrenocortical cells especially from low densities and its use resulted in the achievement of higher saturation densities (Fig. 11).

When saturating concentrations of FGF $(100 \mathrm{ng} / \mathrm{ml})$ and ACTH (10 $\mathrm{nM}$ ) were added together to cultures at each medium change, growth up to about 6 days after plating was not different from cultures treated with $10 \mathrm{nM}$ ACTH alone (Fig. 11). After initial inhibition by ACTH, desensitization occurred and cells initiated growth at a reduced rate. However, after approximately 6 days, there was a marked difference between FGF treated and nontreated cultures. In the absence of FGF, ACTH-treated cells plateaued

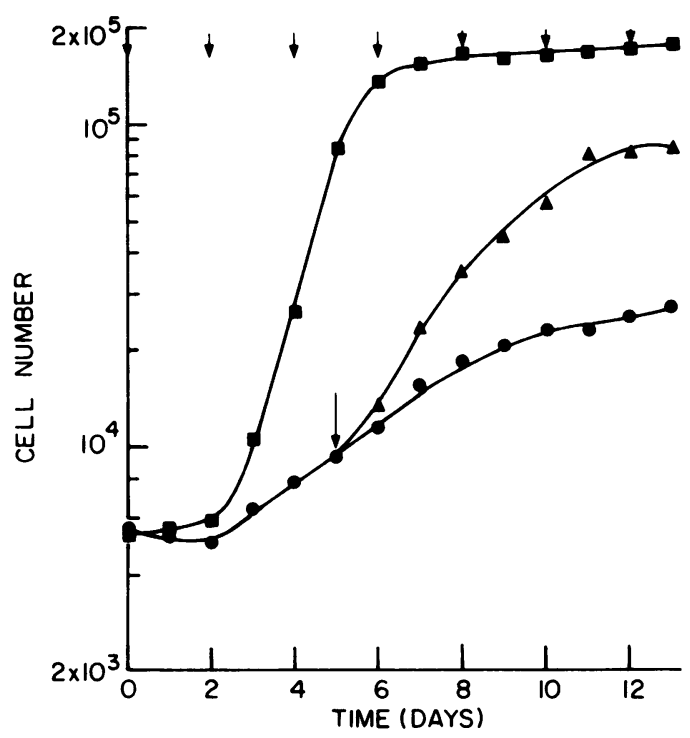

FIguRE 9 Reversibility of ACTH effects on cell growth. Cells were grown in the absence or presence of $10 \mathrm{nM}$ $\mathrm{ACTH}$; the medium was renewed at the times indicated by the arrows at the top of the diagram. At day 5, ACTH was removed from one set of cultures and cells were then maintained in ACTH-free medium. Control cells without ACTH, ( $)$; with ACTH (10 nM), (O); ACTH removal at time indicated by arrow, (A). 


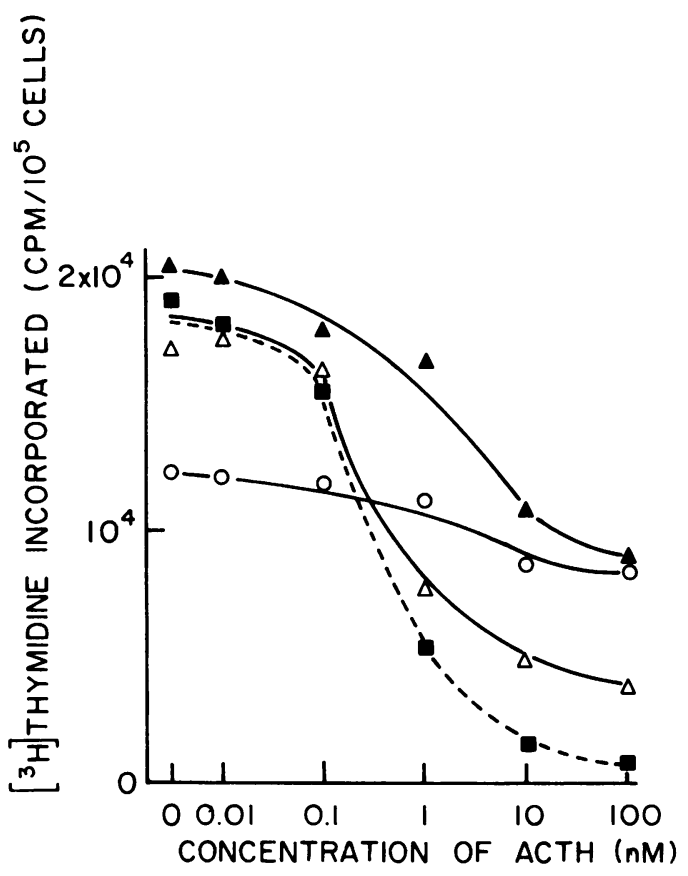

Figure 10 Effect of desensitization to ACTH on subsequent responsiveness to $\mathrm{ACTH}$. Control cells were grown for 4 days without ACTH and desensitized cells were grown for 6 days in the presence of 0.1 or $10 \mathrm{nM}$ ACTH. Hormone was removed by incubation with two washes of normal medium each for $10 \mathrm{~min}$ or by two washes of normal medium each for $4 \mathrm{~h}$. Fresh medium containing the indicated concentrations of ACTH was then added and $16 \mathrm{~h}$ later cells were pulsed for $4 \mathrm{~h}$ with $\left[{ }^{3} \mathrm{H}\right]$ thymidine. Control cells, no pretreatment with ACTH, $(\square)$; pretreatment with ACTH (10 $\mathrm{nM}$ ), 20-min wash, (O); pretreatment with ACTH (10 $\mathrm{mM})$, 8-h wash, $(\Delta)$; pretreatment with ACTH $(0.1 \mathrm{nM})$, 20-min wash, $(\triangle)$.

at a low density. In the presence of FGF, ACTHtreated cells continued to grow at the reduced rate and achieved a cell density at least 10-fold higher than in its absence. FGF thus appears to have no effect on the initial sensitivity of the cells to ACTH because it does not change the dose-response curve of ACTH inhibition of DNA synthesis (Fig. 8), nor does it change the lag time to initiation of growth in the presence of ACTH (Fig. 11). Similarly, FGF failed to alter the reduced growth rate seen in the presence of continuously elevated ACTH levels. The major effect of FGF was to allow continued growth so that significantly higher saturation densities were achieved.

When ACTH was removed from cultures maintained in the presence of FGF, reversibility of ACTH inhibition was again noted (Fig. 11). The growth rate increased to the rapid rate observed in the presence of FGF alone; this rate exceeded that of cells maintained in the presence of FGF and ACTH.

\section{DISCUSSION}

The present results indicate that in cultured normal bovine adrenocortical cells, the continuous presence of high levels of ACTH did not prevent considerable division of adrenal cells from occurring, despite a marked initial inhibition of DNA synthesis. Cells growing in the presence of ACTH retain their adrenalspecific properties and also remain responsive to FGF which causes the cultures to achieve far higher cell densities than is possible in the absence of FGF. If culture conditions reflect in vivo conditions, the adrenal gland could well achieve a long-term increase in cell number, even if ACTH has a direct antimitotic action in vivo and stimulates growth of the adrenal by an indirect mechanism as we have postulated $(4,5$, 7 ). Most of the increase in DNA content in vivo is a late effect of increasing the circulating level of ACTH (9). It may be that in vivo as in culture there is an initial period when ACTH is strongly inhibitory to DNA synthesis, resulting in cellular hypertrophy $(5,8)$, but the cells become desensitized to ACTH and cell division then occurs. The results reported here demonstrate that hormone desensitization may have profound effects on growth control, an aspect of desensiti-

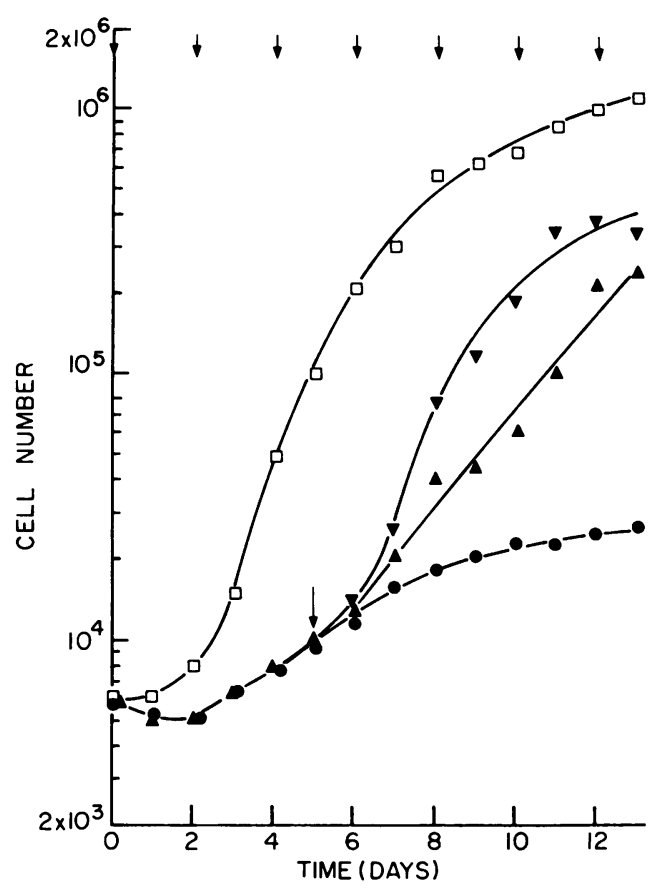

FIGURE 11 Effect of FGF and ACTH on adrenocortical cell growth. Medium containing the indicated concentrations of ACTH and FGF was replenished every 2 days as indicated by the arrows at the top of the diagram. FGF (100 $\mathrm{ng} / \mathrm{ml})$, ( $\square)$; ACTH (10 nM), (๑); FGF (100 ng/ml) plus ACTH (10 nM), (A); FGF (100 ng/ml) plus ACTH (10 nM) until day 5 (arrow) when ACTH was removed and growth continued in the presence of FGF alone, $(\nabla)$. 
zation which has not been considered previously, but which may well be an important mechanism for regulating growth in vivo.

ACTH-induced desensitization to ACTH has not previously been investigated in normal adrenal tissue, but has been shown to occur in the Y-1 adrenal tumor cell line with respect to cAMP production (32). In a variety of other tissues it has now been demonstrated that one effect of treatment of a target tissue with a hormone to which it is responsive is a subsequent decrease either in its cAMP producing potency or its ability to stimulate other biological responses (33-37). Desensitization does not generally extend to hormones other than the one with which the tissue is pretreated, or to factors such as cholera toxin (32). Similar findings were demonstrated for adrenocortical cells. The desensitized adrenal cells remained responsive to the growth inhibitory effects of monobutyryl cAMP, prostaglandin $E_{1}$, and cholera toxin.

In some cases of desensitization in whole cells an actual loss of receptors for the hormone occurs (33, 34,36 ), but desensitization also can occur in vitro in membrane particles from ovarian follicles when stimulated with luteinizing hormone (LH) (37). It has been proposed that the initial readily reversible desensitization is converted in whole cells to a more permanent state (36). For LH desensitization in follicle membranes, cAMP production by LH does not seem to be necessary in that exogenously added cAMP did not induce desensitization. The present experimental treatment of adrenal cells with monobutyryl cAMP also resulted in a steadily maintained inhibition of growth with no development of desensitization to either monobutyryl cAMP or ACTH. This prompted us to test the effects of an ACTH fragment, $\mathrm{ACTH}_{11-24}$, which by binding to ACTH receptors displaces $\mathrm{ACTH}_{1-39}$ or $\mathrm{ACTH}_{1-24}$ and acts as a competitive inhibitor $(26,27)$. Because $\mathrm{ACTH}_{11-24}$ lacks the active site of the ACTH molecule (present in positions 1-10) (38), it has no agonist activity. Pretreatment with this fragment at a high concentration had no desensitizing action. Mere receptor occupancy does not appear sufficient for desensitization; elevated cAMP levels are also insufficient for development of desensitization. Similar specificity for development of desensitization to catecholamines and LH has been reported $(37,39)$. It would be of interest to study the effects of other ACTH fragments or analogs on desensitization to investigate whether separate molecular structural requirements exist for this process.

The present experiments indicate that the desensitized state can be maintained at a constant level over a long period, as shown by the slowed but constant growth rate of cells in the presence of ACTH. The slower rate of growth produced by ACTH is readily reversible; when cells were changed from ACTH- containing medium to a lower concentration or to ACTH-free medium, an increased rate of $\left[{ }^{3} \mathrm{H}\right]$ thymidine incorporation was demonstrable $24 \mathrm{~h}$ later and an increased cell number at $48 \mathrm{~h}$. The rate of growth increased to that seen with serum or, if FGF was added, to that seen with serum plus FGF. However, the desensitization persisted when the cells were incubated in ACTH-free medium for $8 \mathrm{~h}$ before the standard assay for ACTH inhibition of $\left[{ }^{3} \mathrm{H}\right]$ thymidine incorporation. The reversibility of the desensitization phenomenon thus appears slow.

The persistence of effects of FGF in the presence of ACTH is of considerable interest. The present experiments show that FGF can reverse the low saturation density characteristic of ACTH-treated cultures. Because the saturation density achieved with ACTH did not result from accelerated cell death, the effect of FGF on increasing the final cell density did not result from an increase in cell survival. FGF did not affect the slow rate of growth of ACTH-treated cultures nor did pretreatment with FGF affect ACTHinduced inhibition of growth. Consequently, it may be hypothesized that FGF does not directly reverse the mechanism by which ACTH opposes growth. Previously, FGF was shown to be an effective migration stimulating factor, even in the presence of a high concentration of ACTH (4). The action of FGF on migration, saturation density, and growth of cells from very low densities (4) seems to be separate from actual control of growth rate. Whether these phenomena are all expressions of one common initial action of FGF remains to be studied.

It is also unknown at this time whether FGF or an FGF-like molecule is of importance in vivo in stimulating adrenal growth. Some specificity for FGF exists because epidermal growth factor does not affect adrenocortical cell growth (4). An FGF-like molecule has been isolated from the pituitary and shown to be effective in stimulating the growth of ovarian cells in culture (40). The possibility that such a factor may act on adrenocortical cells in vivo is supported by a number of experiments demonstrating growth in response to factors other than ACTH. Growth hormone has been implicated as an adrenal growth stimulator (41) and an adrenal weight-maintaining factor distinct from ACTH was demonstrated in patients with Cushing's syndrome (42). In addition, neural stimulation of the adrenal results in growth by an ACTH-independent mechanism $(43,44)$.

Though ACTH inhibits DNA synthesis acutely, it does not block serum-induced cellular hypertrophy (5); under these conditions, ACTH induces the steroidogenic capacity of the cell (7). This results in a hypertrophied adrenocortical cell with increased steroidogenic potential. With chronically elevated levels of ACTH, desensitization may occur and DNA synthesis 
and cell division follow. The extent of cellular hyperplasia achieved will depend upon the concentrations of ACTH and of the relevant in vivo growth factors. Additional studies are required to determine whether in vivo growth observed in the presence of high concentrations of ACTH results from elevation of growth factor(s) entrained to ACTH or to alterations in cellular responsiveness to constant concentrations of growth factors. The interactions of FGF and ACTH on adrenocortical cells may serve as a model of interactions between growth and differentiation factors in a number of cell types.

\section{ACKNOWLEDGMENTS}

The authors express appreciation to Dr. Denis Gospodarowicz of The Salk Institute for Biological Studies for helpful discussions during the course of these studies and for the generous gift of purified FGF.

This investigation was supported by U. S. Public Health Service research grant AM13149 from the National Institute of Arthritis, Metabolism, and Digestive Diseases.

\section{REFERENCES}

1. Ramachandran, J., and A. T. Suyama. 1975. Inhibition of replication of normal adrenocortical cells in culture by adrenocorticotropin. Proc. Natl. Acad. Sci. U. S. A. 72: 113-117.

2. O'Hare, M. J., and A. M. Neville. 1973. Effects of adrenocorticotrophin on steroidogenesis and proliferation by adult adrenal cells in monolayer culture. Biochem. Soc. Trans. 1: 1088-1091.

3. Masui, H., and L. D. Garren. 1971. Inhibition of replication in functional mouse adrenal tumor cells by adrenocorticotropic hormone mediated by adenosine $3^{\prime}: 5^{\prime}-$ cyclic monophosphate. Proc. Natl. Acad. Sci. U. S. A. 68: 3206-3210.

4. Gospodarowicz, D., C. R. Ill, P. J. Hornsby, and G. N. Gill. 1977. Control of bovine adrenal cortical cell proliferation by fibroblast growth factor. Lack of effect of epidermal growth factor. Endocrinology. 100: 1080-1089.

5. Weidman, E. R., and G. N. Gill. 1977. Differential effects of ACTH or 8-Br-cAMP on growth and replication in a functional adrenal tumor cell line. J. Cell. Physiol. 90: $91-103$.

6. Gospodarowicz, D., and H. H. Handley. 1975. Stimulation of division of Y1 adrenal cells by a growth factor isolated from bovine pituitary glands. Endocrinology. 97: 102-107.

7. Gill, G. N., and E. R. Weidman. 1977. Hormonal regulation of initiation of DNA synthesis and of differentiated function in Y-1 adrenal cortical cells. J. Cell. Physiol. In press.

8. Nickerson, P. A. 1975. Quantitative study of the effect of an ACTH-producing pituitary tumor on the ultrastructure of the mouse adrenal gland. Am. J. Pathol. 80: 295-308.

9. Farese, R. V., and W. J. Reddy. 1963. Observations on the interrelations between adrenal protein, RNA and DNA during prolonged ACTH administration. Biochim. Biophys. Acta. 76: 145-148.

10. Masui, H., and L. D. Garren. 1970. On the mechanism of action of adrenocorticotropic hormone. Stimulation of deoxyribonucleic acid polymerase and thymidine kinase activities in adrenal glands. J. Biol. Chem. 245: 2627-2632.

11. Machemer, R., and W. Oehlert. 1964. Autoradiographische Untersuchungen über den physiologischen Zellumsatz und die gesteigerte Zellneubildung der Nebenniere der ausgewachsenen Ratte nach Behandlung mit ACTH. Endokrinologie. 46: 77-91.

12. Bury, H. P. R., and W. A. J. Crane. 1965. Effect of age and hormonal state on the numbers of deoxyribonucleic acid synthesizing nuclei in rat adrenal cortex. Nature (Lond.). 205: 301-302.

13. Haeuber, H-D. 1965. Zur Regeneration des Nebennierenrindenparenchyms beim Meerschweinchen nach sog. 3/4-Resektion der Nebennierenrinde. Endokrinologie. 48: 255-265.

14. Coon, H. G., and M. C. Weiss. 1969. A quantitative comparison of formation of spontaneous and virus-produced viable hybrids. Proc. Natl. Acad. Sci. U. S. A. 62: 852-859.

15. Holley, R. W., and J. A. Kiernan. 1974. Control of the initiation of DNA synthesis in 3T3 cells: Serum factors. Proc. Natl. Acad. Sci. U. S. A. 71: 2908-2911.

16. Crissman, H. A., and R. A. Tobey. 1974. Cell-cycle analysis in 20 minutes. Science (Wash. D. C.). 184: 1297-1298.

17. Holley, R. W., and J. A. Kiernan. 1974. Control of the initiation of DNA synthesis in 3T3 cells: Low-molecularweight nutrients. Proc. Natl. Acad. Sci. U. S. A. 71: 2942-2945.

18. Silber, R. H. 1966. Fluorimetric analysis of corticoids. Methods Biochem. Anal. 14: 63-78.

19. Bush, I. E. 1953. Species differences and other factors influencing adrenocortical secretion. Ciba Found. Colloq. Endocrinol. 7: 210-232.

20. O'Hare, M. J. 1976. Monolayer cultures of normal adult rat adrenocortical cells: Steroidogenic responses to nucleotides, bacterial toxins and antimicrotubular agents. Experientia (Basel). 32: 251-253.

21. O'Hare, M. J., and A. M. Neville. 1973. The steroidogenic response of adult rat adrenocortical cells in monolayer culture. J. Endocrinol. 56: 537-549.

22. O'Hare, M. J., and A. M. Neville. 1973. Steroid metabolism by adult rat adrenocortical cells in monolayer culture. J. Endocrinol. 58: 447-462.

23. Kowal, J. 1969. Adrenal cells in tissue culture. III. Effect of adrenocorticotropin and $3^{\prime}, 5^{\prime}$-cyclic adenosine monophosphate on $11 \beta$-hydroxylase and other steroidogenic enzymes. Biochemistry. 8: 1821-1831.

24. Dexter, R. N., L. M. Fishman, R. L. Ney, and G. W. Liddle. 1967. Inhibition of adrenal corticosteroid synthesis by aminoglutethimide: Studies of the mechanism of action. J. Clin. Endocrinol. Metab. 27: 473480.

25. O'Hare, M. J., and A. M. Neville. 1973. Morphological responses to corticotrophin and cyclic AMP by adult rat adrenocortical cells in monolayer culture. J. Endocrinol. 56: 529-536.

26. Seelig, S., and G. Sayers. 1973. Isolated adrenal cortex cells: ACTH agonists, partial agonists, antagonists; cyclic AMP and corticosterone production. Arch. Biochem. Biophys. 154: 230-239.

27. Saez, J. M., A. M. Morera, A. Dazord, and P. Bataille. 1974. Interactions of ACTH with its adrenal receptors: Specific binding of $\mathrm{ACTH}_{1-24}$, its o-nitrophenyl sulfenyl derivative and $\mathrm{ACTH}_{11-24}$. J. Steroid Biochem. 5: 925933.

28. Grahame-Smith, D. G., R. W. Butcher, R. L. Ney, and E. W. Sutherland. 1967. Adenosine $3^{\prime}, 5^{\prime}$-monophos- 
phate as the intracellular mediator of the action of adrenocorticotropic hormone on the adrenal cortex. $J$. Biol. Chem. 242: 5535-5541.

29. Saruta, T., and N. M. Kaplan. 1972. Adrenocortical steroidogenesis: the effects of prostaglandins. J. Clin. Invest. 51: 2246-2251.

30. Haksar, A., D. V. Maudsley, and F. G. Peron. 1975. Stimulation of cyclic adenosine $3^{\prime}: 5^{\prime}$-monophosphate and corticosterone formation in isolated rat adrenal cells by cholera enterotoxin. Comparison with the effects of ACTH. Biochim. Biophys. Acta. 381: 308-323.

31. Saez, J. M., A. Dazord, A. M. Morera, and P. Bataille. 1975. Interactions of adrenocorticotropic hormone with its adrenal receptors. Degradation of $\mathrm{ACTH}_{1-24}$ and ACTH $_{11-24}$. J. Biol. Chem. 250: 1683-1689.

32. Wishnow, R. M., E. Lifrak, and C-C. Chen. 1976. Mode of action of Vibrio cholerae enterotoxin in cultured adrenal tumor cells. J. Infect. Dis. 133: S108-S114.

33. Gavin, J. R., III, J. Roth, D. M. Neville, Jr., P. de Meyts, and D. N. Buell. 1974. Insulin-dependent regulation of insulin receptor concentrations: A direct demonstration in cell culture. Proc. Natl. Acad. Sci. U. S. A. 71: 84-88.

34. Hinkle, P. M., and A. H. Tashjian, Jr. 1975. Thyrotropinreleasing hormone regulates the number of its own receptors in the $\mathrm{GH}_{3}$ strain of pituitary cells in culture. Biochemistry. 14: 3845-3851.

35. Mukherjee, C., M. G. Caron, and R. J. Lefkowitz. 1975. Catecholamine-induced subsensitivity of adenylate cyclase associated with loss of $\beta$-adrenergic receptor binding sites. Proc. Natl. Acad. Sci. U. S. A. 72: 1945-1949.
36. Mukherjee, C., and R. J. Lefkowitz. 1976. Desensitization of $\beta$-adrenergic receptors by $\beta$-adrenergic agonists in a cell-free system: Resensitization by guanosine $3^{\prime}$ $(\beta, \gamma$-imino)triphosphate and other purine nucleotides. Proc. Natl. Acad. Sci. U. S. A. 73: 1494-1498.

37. Bockaert, J., M. Hunzicker-Dunn, and L. Birnbaumer. 1976. Hormone-stimulated desensitization of hormonedependent adenylyl cyclase. J. Biol. Chem. 251: 26532663.

38. Hofmann, K. 1974. Relations between chemical structure and function of adrenocorticotropin and melanocytestimulating hormones. Handb. Physiol. 4(2)(Sect. 7. Endocrinology.): 29-58.

39. Mukherjee, C., M. G. Caron, and R. J. Lefkowitz. 1976. Regulation of adenylate cyclase coupled $\beta$ adrenergic receptors by $\beta$-adrenergic catecholamines. Endocrinology. 99: 347-357.

40. Jones, K. L., and D. Gospodarowicz. 1974. Biological activity of a growth factor for ovarian cells. Proc. Natl. Sci. U. S. A. 71: 3372-3376.

41. Cater, D. B., and M. P. Stack-Dunne. 1955. The effects of growth hormone and corticotrophin upon the adrenal weight and adrenocortical mitotic activity in the hypophysectomized rat. J. Endocrinol. 12: 174-184.

42. Segal, B. M., and N. P. Christy. 1968. Potentiation of the biologic activity of ACTH by human plasma. A preliminary study. J. Clin. Endocrinol. 28: 1465-1472.

43. Engeland, W. C., J. Shinsako, and M. F. Dallman. 1975. Corticosteroids and ACTH are not required for compensatory adrenal growth.Am.J. Physiol. 229: 1461-1464.

44. Engeland, W. C., and M. F. Dallman. 1975. Compensatory adrenal growth is neurally mediated. Neuroendocrinology. 19: 352-362. 